\title{
Are there activated chemical defenses in sponges of the genus Aplysina from the Caribbean?
}

\author{
Monica Puyana ${ }^{1}$, William Fenical ${ }^{1}$, Joseph R. Pawlik ${ }^{2, *}$ \\ ${ }^{1}$ Center for Marine Biotechnology and Biomedicine, Scripps Institution of Oceanography, University of California, \\ San Diego, La Jolla, California 92093-0204, USA \\ ${ }^{2}$ Biological Sciences and Center for Marine Science, University of North Carolina at Wilmington, Wilmington, \\ North Carolina 28409, USA
}

\begin{abstract}
The Mediterranean sponge Aplysina aerophoba has been proposed to rely on damageinduced activation of chemical defenses against pathogens and fish predators. High molecular weight brominated tyrosine derivatives have been suggested to undergo rapid, enzyme-mediated transformations into the metabolites aeroplysinin-1 and dibromocyclohexadienone following tissue damage, a process also called 'biotransformation'. These putative end-products were found to exhibit greater defensive activity compared to their precursors. Because sponges of the genus Aplysina possess similar chemical components worldwide, it has been suggested that the activation of chemical defenses is a common feature in this group. Herein, we report in situ and laboratory experiments conducted with living specimens of 2 species from the Caribbean, Aplysina insularis and A. archeri. Changes in sponge tissue secondary metabolites during time-course experiments were determined using diode-array high performance liquid chromatography coupled with mass spectrometry (LCMS) analyses of extracts of flash frozen samples. We obtained no evidence of chemical transformation after tissue damage. In short (150 s) and long (30 and $120 \mathrm{~min}$ ) time-course experiments, conversion of the major high molecular weight brominated constituents into the low molecular weight aeroplysinin-1 or dibromocyclohexadienone was not apparent: there was neither a reduction in the concentration of putative precursor metabolites, nor an increase in end products. Past observations of transformation may be the result of differential tissue extraction efficiency, hydrolysis from insoluble precursors or the heterogeneous distribution of metabolites in sponge tissue.
\end{abstract}

KEY WORDS: Sponge $\cdot$ Aplysina $\cdot$ Biotransformation $\cdot$ Activation $\cdot$ Chemical defense $\cdot$ Caribbean Resale or republication not permitted without written consent of the publisher

\section{INTRODUCTION}

Secondary metabolites are thought to play important roles in defending sessile benthic marine invertebrates from predators, competitors and pathogens (see reviews, Pawlik 1993, McClintock \& Baker 2001). Optimal defense theory predicts that defensive metabolites may be differentially allocated to the parts of the organism more susceptible to predation, or that defensive metabolites may be induced in response to predation (Rhoades 1979). The latter process, induction, involves the initiation of metabolite synthesis in response to tissue damage. Unlike induction, which is

*Corresponding author. Email: pawlikj@uncwil.edu a slow process, activation has been described as a rapid process in which innocuous metabolites that are stored in the tissue are converted to defensive metabolites in response to tissue damage (reviewed in Paul 1992). The advantage of activated defenses to organisms that possess them is not one of optimization (because the energy involved in production has already been expended), but rather the avoidance of autotoxicity.

The activation of defenses has been widely documented in terrestrial plants. Cyanogenic plants are rich in glycosides composed of a cyanohydrin-type aglycone and a sugar moiety. Cyanogenic glycosides 
and their hydrolyzing enzymes are stored in different tissue compartments preventing large scale hydrolysis in intact plant tissue (Vetter 2000). Upon tissue damage, the glycosides are hydrolyzed, and $\mathrm{HCN}$, which is toxic to non-specialist grazers, is released (Vetter 2000). Cruciferous plants store glucosinolates that act as feeding deterrents for polyphagous herbivores, whereas they are feeding stimulants for specialists (Bartlet et al. 1999). Glucosinolates by themselves have limited biological activity, but upon enzymatic degradation by the enzyme myrosinase, they are converted into thiocyanates and isothyocyanates, very toxic compounds with greater allelochemical capabilities (Borek et al. 1998).

In aquatic systems, Pohnert (2000) has recently reported activated chemical defenses in freshwater diatoms. Upon cell damage, oxidative transformation of eicosanoic fatty acids leads to a rapid onset of C-10 unsaturated aldehyde production in Thalassiosira rotula and C-12 unsaturated acids in Asterionella formosa. The product metabolites of this transformation inhibit the growth of filamentous fungi, and deter feeding and reduce hatching success of grazing amphipods (reviewed in Pohnert 2000).

In the marine environment, few cases of activation of defenses have been reported (see Cronin 2001). Tropical chlorophyte algae of the genus Halimeda rapidly convert the diterpenoid halimedatetraacetate into halimedatrial after tissue damage, the latter being more deterrent to herbivorous fishes than the former (Paul \& Van Alstyne 1992). The related alga, Udotea flabellum, uses a very similar mechanism, with udoteal being converted to petiodial (Paul 1992).

Recent studies with the Mediterranean and Eastern Atlantic sponge Aplysina aerophoba have been interpreted to suggest that a series of high molecular weight, brominated secondary metabolites undergo rapid, enzyme-mediated transformation in response to tissue damage (Teeyapant \& Proksch 1993, Teeyapant et al. 1993a,b). The putative final products of this biotransformation (dibromocyclohexadienone and aeroplysinin-1; see Fig. 1) exhibit enhanced antimicrobial activity and cytotoxicity (Weiss et al. 1996), as well as feeding deterrence (Ebel et al. 1997), compared to their precursors. Kreuter et al. (1992) proposed that these compounds may be involved in host defense mechanisms against pathogens or may serve as controlling agents of the symbiotic microbes in the sponge. Ebel et al. (1997) claimed that enzyme extracts of other Aplysina species from the Caribbean would catalyze the same reactions using precursor material from A. aerophoba. None of the experiments that support activation of chemical defenses in $A$. aerophoba were conducted with living sponge tissue.
Sponges of the genus Aplysina (Order Verongida) are soft and fleshy, and lack siliceous spicules. Chemically, they are characterized by a high content of sterols, generally with the modified aplystane skeleton, and they all synthesize a series of brominated metabolites derived from tyrosine (Tymiak \& Rinehart 1981, Bergquist \& Wells 1983, Ciminiello et al. 1994, 1996). The compounds derived from bromotyrosine appear to be stored in spherulous cells and are not associated with any of the diverse microbial symbionts found in the sponge mesohyl, suggesting that they are synthesized by the sponge (Thompson et al. 1983, Turon et al. 2000). Sponges of the genus Aplysina are found in the Eastern Pacific, Eastern and Western Atlantic, and in the Mediterranean, but are particularly diverse and abundant in Florida, the Bahamas and the Caribbean (Wiedenmayer 1977, Van Soest 1978, Zea 1987).

We previously completed a survey of the chemical, structural and nutritional defenses of 71 species of Caribbean demosponges against predatory reef fishes (Chanas \& Pawlik 1995, Pawlik et al. 1995). Although the majority (69\%) of sponge species yielded crude organic extracts that were unpalatable when incorporated into food pellets and presented to the reef fish Thalassoma bifasciatum, all 5 species in the genus Aplysina yielded crude extracts that were highly unpalatable (mean consumption <1 of 10 pellets eaten; Pawlik et al. 1995). Tissue of Aplysina spp. contained moderate to high concentrations of soluble protein (20 to $40 \mathrm{mg} \mathrm{ml}^{-1}$ ) and high energy content ( 2 to $4 \mathrm{~kJ} \mathrm{ml}^{-1}$ ), suggesting that these sponges could provide predators with a good source of nutrition (Chanas \& Pawlik 1995). Because their tissues are neither tough (tensile strength $<1 \times$ $10^{6} \mathrm{~N} \mathrm{~m}^{-2}$ ), nor structurally defended (Chanas \& Pawlik 1995), it appears that these sponges owe much of their ecological success to chemical defenses.

The study described herein was initiated to determine whether the activation process previously described for the chemical defense of Aplysina aerophoba in the Mediterranean was also present in the tissues of Aplysina spp. in the Caribbean. Unlike previous experiments with $A$. aerophoba, we investigated changes in the chemistry of living sponges both in situ and in the laboratory. The first 2 in situ experiments were designed to examine changes in sponge chemistry in response to wounding over a long time course (30 and $120 \mathrm{~min}$ ) using different extraction techniques and with replicate samples. Subsequent in vivo laboratory experiments were performed for a much shorter time course $(150 \mathrm{~s})$, but without replication, to determine whether very rapid changes might be taking place. 


\section{MATERIALS AND METHODS}

Sponge collection. All sponges used for experiments and chemical analyses were either removed by detaching them with substratum, or by cutting them from the substratum with a minimum of tissue damage using a sharp knife. Sponges were individually bagged underwater. Once at the surface, water was quickly poured out of each bag, then the bag was resealed and immersed in a dry ice/acetone bath $\left(-78^{\circ} \mathrm{C}\right)$ to flash freeze the sponge tissue. Sponges were stored in a $-20^{\circ} \mathrm{C}$ freezer until extraction. The volume of all sponge samples was determined by displacement in water or solvent. Long-term time-course experiments were performed on Aplysina insularis (=A. fistularis forma insularis) because this species is abundant on shallow water reefs throughout Florida and the Bahamas, and because the relative proportions of secondary metabolites is highly consistent between specimens collected throughout this region (Puyana 2001).

In situ experiment. Bahamas: The first experiment was performed on 28 July 1999 at Sweetings Cay, Bahamas Islands, on a reef flat at $14 \mathrm{~m}$ depth. Four replicate specimens of Aplysina insularis were located, separated from each other at a distance of $>5 \mathrm{~m}$ (to avoid clones), and each consisted of 2 short tubes ( $6 \mathrm{~cm}$ in diameter and height). At $t_{0}(t=$ time, representing the initial, unharmed condition), one of the tubes was quickly removed from the substrate, bagged, sent to the surface and flash frozen. The remaining tube was stabbed repeatedly with a scalpel to a depth of 1 to $2 \mathrm{~cm}$ over its entire surface (replicating wounding) for $\sim 15 \mathrm{~s}$. Radial, wedge-shaped slices of this tube were cut at $5,10,15$ and 30 min after wounding, bagged, sent to the surface and flash frozen. This process was repeated for each of the 4 replicate specimens. Tissue samples were freeze dried before extraction.

Freeze-dried samples were ground to a powder and then exhaustively extracted with a 1:1 dichloromethane/acetonitrile (DCM/CH $\left.\mathrm{CH}_{3} \mathrm{CN}\right)$ mixture. Extracts were filtered, dried by vacuum rotary evaporation and stored under nitrogen in the freezer. In preparation for liquid chromatography coupled with mass spectrometry (LC-MS), crude extracts were passed through a reverse phase $\mathrm{C}-18$ cartridge and eluted with 1:1 $\mathrm{MeCN} /$ water in order to remove fats, sterols and pigments from samples. The secondary metabolite composition in the crude extracts was analyzed by LC-MS using a diode array HPLC coupled to an electro-spray ionization (ESI) Mass Spectrometer (Hewlett-Packard 1090 and HP1100). Aliquots of the crude extract were redissolved in $\mathrm{MeOH}$ at a concentration of $1 \mathrm{mg} \mathrm{ml}^{-1}$ for HPLC analysis. Separation was achieved using a Dynamax reverse phase C-18 analytical column (60 $\AA, 4.6 \mathrm{~mm}$ in diameter $\times 250 \mathrm{~mm}$ in length) with a
water/MeCN (10 to $100 \%$ ) gradient acidified with

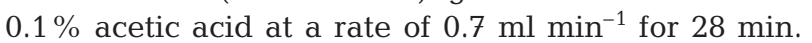
Compounds were detected at $254 \mathrm{~nm}$ and identified on the basis of their retention times, UV and MS spectra. Quantification was carried out using pure compounds as external standards based on peak calibration curves. The bromine in these compounds gives a very distinctive fragmentation pattern, due to differences in the isotopes giving specific masses of fragment ions and characteristic mass differences between the molecular ion, and fragment ions. The identity of the metabolites in the mixture was further corroborated by comparison against the external standards which had been analyzed by ${ }^{1} \mathrm{H}$ and ${ }^{13} \mathrm{C}$ nuclear magnetic resonance (NMR) spectroscopy in order to confirm their structures by comparing with data reported in the literature.

Florida Keys: We carried out the same experiment as described above, but the time course was longer and the sponge tissue samples were not freeze dried before extraction. This experiment was performed on 17 July 2000 at North Key Largo Dry Rocks Reef, Key Largo, Florida, on a reef flat at $\sim 9 \mathrm{~m}$ depth. Wedge-shaped samples of wounded tissue were taken from 4 replicates of Aplysina insularis at 5, 15, 30, 60 and $120 \mathrm{~min}$.

Frozen tissue samples were immersed in acetone and exhaustively extracted, first with acetone and then with a mixture of 1:1 DCM/ $\mathrm{CH}_{3} \mathrm{CN}$. Extracts were pooled, filtered through celite and dried by vacuum rotary evaporation. The remaining extract and aqueous layer was partitioned against ethyl acetate (EtOAc) to yield the crude extract, which was stored under nitrogen in the freezer. Metabolite composition of the crude extract was analyzed by LC-MS (HP 1100) using the same conditions as described above.

In vivo laboratory experiment, Bahamas. Shortterm time-course experiments were performed on freshly collected specimens of Aplysina insularis and $A$. archeri in the laboratory on-board the RV 'Seward Johnson' on 26 July 2000 at Sweetings Cay, Grand Bahama Island, with sponges collected from $\sim 25$ and $\sim 15 \mathrm{~m}$ depth, respectively. As before, specimens used for experiments consisted of 2 tubes. Sponges were carefully detached from the reef, bagged in large ziplock bags and brought to the surface where they were kept in aquaria until the analyses were performed (<30 min after collection). The protocol was identical to the long-term time-course experiments, except that tissue samples were flash frozen at 30,60, 90, 120 and $150 \mathrm{~s}$ after the sponge was wounded. Tissue samples were taken by coring the sponge with a $5 \mathrm{ml}$ plastic syringe with its tip cut off. Use of this corer allowed for a fast retrieval of the tissue sample, minimal manipulation and a relatively uniform sample size (approximately $1 \mathrm{ml}$ ). Samples were placed in 
<smiles>NC(=O)CC1(O)C=C(Br)C(=O)C(Br)=C1</smiles>

Dibromocyclohexadienone (1)<smiles>COC1=C(Br)[C@H](O)[C@](O)(CC#N)C=C1Br</smiles>

Aeroplysinin 1 (2)<smiles>[X][N]C(=O)C1=NO[C@]2(C=C(Br)C(OC)=C(Br)[C@H]2O)C1</smiles><smiles>CCCC(O)CC</smiles>

Hydroxyaerothionin (3)

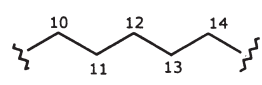

Homoaerothionin (5)<smiles>CCC(=O)C(O)CC</smiles>

Hydroxy-oxo-aerothionin (4)<smiles>CCCCCCC</smiles>

Aerothionin (6)<smiles>CNCC(O)COc1c(Br)cc(C(O)CN)cc1Br</smiles>

Fistularin 3 (7)

Fig. 1. Brominated compounds identified and quantified in in situ and laboratory experiments with Aplysina insularis and $A$. archeri

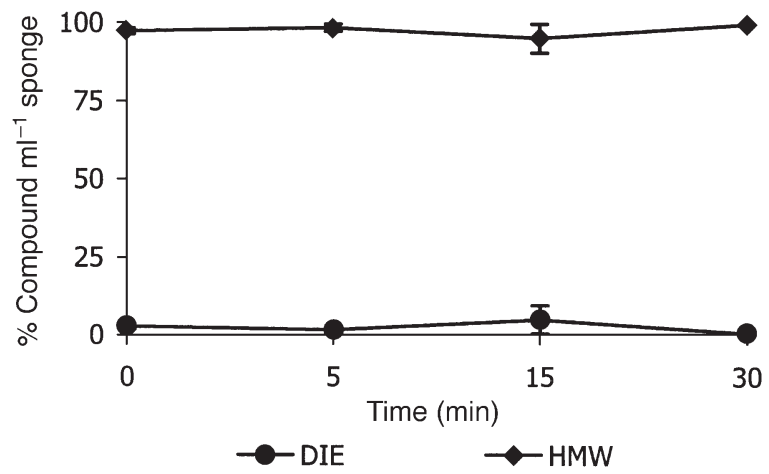

Fig. 2. Aplysina insularis. Bahamas in situ experiment. Variation in the composition of brominated metabolites in sponge tissue after wounding $(\mathrm{n}=4)$. Percentage of total brominated metabolites as high molecular weight compounds (HMW) versus low molecular weight compounds: dibromocyclohexadienone (DIE) in crude extracts of freeze-dried sponge tissue over a $30 \mathrm{~min}$ time course (Table 1). Compounds (3) to (7) pooled as HMW (Fig. 1). Vertical bars represent SE. Aeroplysinin-1 (2) was not detected in freeze-dried material small plastic tubes and flash frozen in the dry ice/acetone bath. After the conclusion of the experiment, samples were kept frozen at $-20^{\circ} \mathrm{C}$ until further analysis. Tissue samples were extracted and analyzed as before. This experiment was performed only once for each species.

\section{RESULTS}

Time-dependent conversion of high molecular weight brominated metabolites into lower molecular weight metabolites was not evident in any of the experiments. The low molecular weight compound dibromocyclohexadienone (Fig. 1) made up $<4 \%$ of the total mixture of brominated metabolites throughout the $30 \mathrm{~min}$ time course of the first experiment (Fig. 2, Table 1). The other low molecular weight compound, aeroplysinin-1 (Fig. 1), was not detected in extracts of freeze-dried material in this experiment. Among the high molecular weight compounds that made up $>95 \%$ of the brominated metabolites throughout this experiment, fistularin 3 (Fig. 1) was consistently the most abundant (Table 1). Although the relative concentration of brominated metabolites was consistent in the sponge samples analyzed in this experiment (Fig. 2), the actual concentration of each metabolite in the samples was highly variable, as reflected in the high SE values in Table 1.

Overall concentrations of brominated metabolites were higher in the tissues of specimens of Aplysina insularis from Florida in the second long-term timecourse experiment $\left(\right.$ mean $=4.58 \mathrm{mg} \mathrm{ml}^{-1}$ compared to $2.01 \mathrm{mg} \mathrm{ml}^{-1}$; Table 2); however, the relative concentrations of small molecular weight compounds did not change relative to the high molecular weight compounds over the $120 \mathrm{~min}$ time course (Figs. 3 \& 4).

Table 1. Aplysina insularis. Variation in the composition of brominated secondary metabolites in crude extracts of Bahamas samples of the sponge after wounding $(n=4)$. Sponges were wounded in situ and tissue samples were collected over a $30 \mathrm{~min}$ period. Tissue samples were freeze dried prior to extraction. Quantities expressed in mg of compound per milliliter of sponge tissue $\pm \mathrm{SE}$. $\mathrm{C}=$ compound numbers, which follow Fig. 1

\begin{tabular}{|ccccc|}
\hline $\mathbf{C}$ & \multicolumn{4}{c}{ Time (min) } \\
& 0 & 5 & 15 & 30 \\
\hline $\mathbf{1}$ & $0.04 \pm 0.02$ & $0.04 \pm 0.03$ & $0.06 \pm 0.05$ & $0.01 \pm 0.01$ \\
$\mathbf{3}$ & $0.30 \pm 0.12$ & $0.32 \pm 0.04$ & $0.26 \pm 0.07$ & $0.29 \pm 0.08$ \\
$\mathbf{4}$ & $0.37 \pm 0.17$ & $0.40 \pm 0.02$ & $0.36 \pm 0.14$ & $0.33 \pm 0.06$ \\
$\mathbf{5}$ & $0.38 \pm 0.16$ & $0.43 \pm 0.08$ & $0.33 \pm 0.06$ & $0.40 \pm 0.12$ \\
$\mathbf{6}$ & $0.25 \pm 0.10$ & $0.28 \pm 0.06$ & $0.22 \pm 0.03$ & $0.29 \pm 0.09$ \\
$\mathbf{7}$ & $0.71 \pm 0.33$ & $0.70 \pm 0.09$ & $0.69 \pm 0.23$ & $0.58 \pm 0.10$ \\
\hline
\end{tabular}


Table 2. Aplysina insularis. Variation in the composition of brominated secondary metabolites in crude extracts of Florida samples of the sponge after wounding $(\mathrm{n}=4)$. Sponges were wounded in situ and tissue samples collected over a 120 min period. Tissue samples were frozen prior to extraction. Quantities expressed in mg of compound per ml of sponge tissue \pm SE. C $=$ compound numbers, which follow Fig. 1

\begin{tabular}{|c|c|c|c|c|c|c|}
\hline \multirow[t]{2}{*}{$\mathrm{C}$} & \multicolumn{6}{|c|}{ Time (min) } \\
\hline & 0 & 5 & 15 & 30 & 60 & 120 \\
\hline 1 & $0.28 \pm 0.07$ & $0.39 \pm 0.14$ & $0.49 \pm 0.22$ & $0.24 \pm 0.08$ & $0.18 \pm 0.05$ & $0.24 \pm 0.03$ \\
\hline 2 & $0.42 \pm 0.04$ & $0.50 \pm 0.17$ & $0.54 \pm 0.12$ & $0.60 \pm 0.16$ & $0.70 \pm 0.12$ & $0.67 \pm 0.13$ \\
\hline 3 & $0.59 \pm 0.03$ & $0.51 \pm 0.08$ & $0.36 \pm 0.05$ & $0.42 \pm 0.05$ & $0.54 \pm 0.07$ & $0.53 \pm 0.10$ \\
\hline 4 & $0.68 \pm 0.12$ & $0.62 \pm 0.15$ & $0.50 \pm 0.10$ & $0.57 \pm 0.13$ & $0.74 \pm 0.08$ & $0.66 \pm 0.08$ \\
\hline 5 & $0.63 \pm 0.31$ & $0.40 \pm 0.09$ & $0.28 \pm 0.08$ & $0.38 \pm 0.13$ & $0.43 \pm 0.11$ & $0.45 \pm 0.14$ \\
\hline 6 & $0.84 \pm 0.20$ & $0.49 \pm 0.09$ & $0.30 \pm 0.06$ & $0.39 \pm 0.11$ & $0.47 \pm 0.11$ & $0.54 \pm 0.20$ \\
\hline 7 & $1.33 \pm 0.23$ & $0.92 \pm 0.19$ & $0.67 \pm 0.14$ & $0.73 \pm 0.20$ & $0.88 \pm 0.17$ & $0.90 \pm 0.19$ \\
\hline
\end{tabular}

Again, actual concentrations of specific metabolites were highly variable, as reflected in the HPLC traces of extracts from tissue samples from the same sponge (Fig. 4) and the high SE values for replicate experiments (Table 2). Among the low molecular weight compounds, aeroplysinin-1 (Fig. 1) was present in this experiment and was consistently detected in higher concentrations than dibromocyclohexadienone (Figs. 1 $\& 2$, Table 2). As with the first experiment on Bahamas sponges, fistularin 3 (Fig. 1) was the dominant high molecular weight metabolite (Table 2).

The short-term time-course experiment with tissue of Aplysina insularis did not reveal any differences in the relative concentrations of brominated metabolites during the first $90 \mathrm{~s}$ after wounding relative to the long-term experiments (Fig. 5). Aeroplysinin-1 made up a high percentage ( $32 \%$ ) of the compound mixture for the tissue sample collected at $150 \mathrm{~s}$. This experiment was not replicated and individual tissue concentration values reflect the variation that was also seen in the long-term time-course experiments. The concentrations of brominated metabolites in tissue samples

Table 3. Aplysina insularis. Short-time variation in the composition of brominated secondary metabolites in Bahamas samples of the sponge seconds after wounding $(n=1)$. Sponges were wounded and tissue samples collected over a 150 s period. Quantities expressed in mg of compound per $\mathrm{ml}$ of sponge tissue. $\mathrm{C}=$ compound numbers, which follow Fig. 1

\begin{tabular}{|ccccccc|}
\hline \multirow{2}{*}{} & \multicolumn{7}{c|}{ Time (s) } \\
& 0 & 30 & 60 & 90 & 120 & 150 \\
\hline $\mathbf{1}$ & 0.01 & 0.09 & 0.13 & 0.17 & 0.53 & 0.39 \\
$\mathbf{2}$ & 0.24 & 0.28 & 0.84 & 1.21 & 0.36 & 1.75 \\
$\mathbf{3}$ & 0.54 & 0.22 & 0.49 & 0.72 & 0.13 & 0.45 \\
$\mathbf{4}$ & 1.32 & 0.25 & 0.67 & 0.94 & 0.23 & 0.69 \\
$\mathbf{5}$ & 0.51 & 0.23 & 0.52 & 0.79 & 0.14 & 0.45 \\
$\mathbf{6}$ & 0.23 & 0.20 & 0.43 & 0.65 & 0.13 & 0.38 \\
$\mathbf{7}$ & 1.06 & 0.49 & 1.10 & 1.64 & 0.97 & 1.21 \\
\hline
\end{tabular}

taken during this experiment ranged from 1.76 to $6.12 \mathrm{mg} \mathrm{ml}^{-1}$ (Table 3).

The short-term time-course experiment with tissue of Aplysina archeri exhibited the same relative concentration of brominated metabolites as was seen in previous short- and long-term experiments with A. insularis, with a consistent predominance of high molecular weight metabolites (Fig. 6), except for the tissue sample taken at $30 \mathrm{~s}$, which had the lowest total metabolite concentration (5.81 $\mathrm{mg} \mathrm{ml}^{-1}$ ) but a higher relative concentration of the low molecular weight compounds. Again, this experiment was not replicated and individual tissue concentration values reflect the variation that was also seen in the long-term time-course experiments

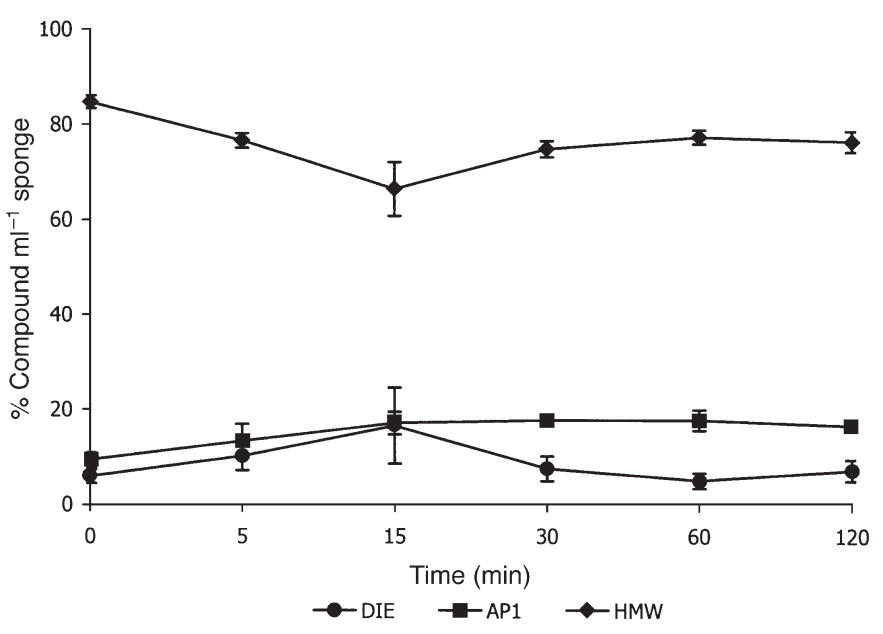

Fig. 3. Aplysina insularis. Florida in situ experiment. Variation in the composition of brominated metabolites in sponge tissue after wounding $(n=4)$. Percentage of total brominated metabolites as high molecular weight compounds (HMW) versus low molecular weight compounds: dibromocyclohexadienone (DIE, [1]) and aeroplysinin-1 (AP1, [2]) in crude extracts of frozen sponge tissue over a $120 \mathrm{~min}$ time course (Table 2). Compounds (3) to (7) pooled as HMW (Fig. 1). Vertical bars represent SE 

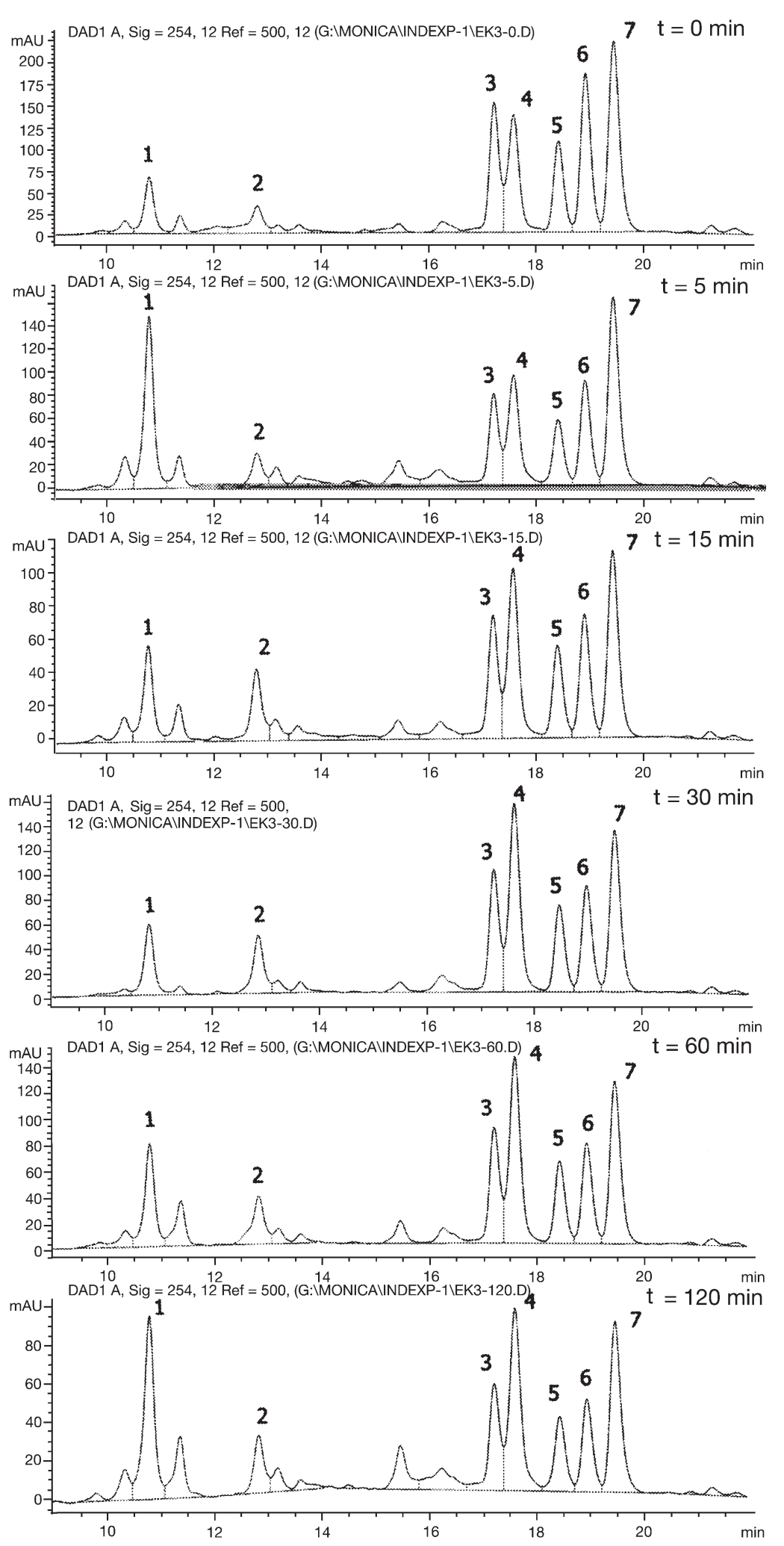

Fig. 4. Aplysina insularis. Comparative high performance liquid chromatography (HPLC) analysis of the composition of brominated metabolites in crude extracts of sponge tissue samples taken over a 120 min time course. Data shown here incorporated as 1 replicate of means shown in Fig. 3. Compound numbers follow Fig. 1 with A. insularis. The concentrations of brominated metabolites in tissue samples taken during this experiment ranged from 5.81 to $37.7 \mathrm{mg} \mathrm{ml}^{-1}$ (Table 4).

\section{DISCUSSION}

We found no evidence for an activation of defensive metabolites after tissue damage to Aplysina insularis or $A$. archeri. There was neither an increase in the concentration of low molecular weight brominated metabolites, nor a concomitant decrease in the concentration of high molecular weight metabolites over the course of the replicated wounding experiments using A. insularis, regardless of whether the tissue was freeze dried and extracted (Fig. 2) or extracted wet (Figs. 3 \& 4). To compliment the replicated experiments, non-replicated, short-term experiments with $A$. insularis and $A$. archeri were performed to determine if changes in chemistry might be occurring in the first $150 \mathrm{~s}$ after sponge wounding (Figs. 5 \& 6); these laboratory experiments also permitted immediate flash freezing because samples did not need to be transported up from the reef. Although a few of the data points from the short-term time-course experiment revealed higher levels of low molecular weight compounds (Figs. 5 \& 6, 150 and 30 s, respectively), these individual data points only reflect the high level of variation in chemistry seen in the individual tissue samples analyzed in the replicated, long-term experiments. The short-term laboratory experiments, which offered more precision in timing than the long-term experiments done in the field, confirmed that transformation of high molecular weight metabolites into low molecular weight metabolites was not occurring within seconds after wounding live sponge tissue, and further replication of the short-term experiments was not performed.

This study revealed that there was considerable heterogeneity in the distribution of metabolites within individual sponges. Although the relative proportions of metabolites remained fairly constant, absolute concentrations varied considerably from sample to sample of an individual sponge. This variation is reflected in the high SE values for the data in the long-term time-course experiments with Aplysina insularis (SE often 25 to 
$50 \%$ of the mean, $\mathrm{n}=4 ;$ Table 1 ) and the data from the short-term time course experiments, where individual samples from the same specimen of $A$. insularis contained a range of total brominated metabolites of 1.76 to $6.12 \mathrm{mg} \mathrm{ml}^{-1}$ (>3-fold difference), and samples from A. archeri contained a range of 5.81 to $37.7 \mathrm{mg} \mathrm{ml}^{-1}$ ( $>6$-fold difference). Variation between samples from the same sponge is also evident in the HPLC traces shown in Fig. 4, which represent one of the 4 replicate sets of time-course data, the mean of which is presented in Fig. 3. Throughout this study, tissue samples were taken to best represent the whole sponge, i.e. radial wedges and cores that included similar proportions of surface and internal tissues. It is therefore apparent that metabolites are not homogeneously distributed within the sponge body, let alone between surface and internal tissues. The presence of 'hot spots' of metabolites complicate studies such as this, where an individual sponge is considered a homogenous unit for the purpose of time-course experiments. However, the lack of a change in the relative proportion of the metabolites making up the mixture of brominated metabolites is sufficient to falsify the hypothesis that activation of metabolites is occurring in these 2 species of Aplysina.

In addition to variation in metabolite concentration within individual sponges, there was ample variation between species and between locations. The present study was part of an in-depth chemical analysis of 10 species of Aplysina from several locations in the Bahamas and Florida (Puyana 2001). Mean concentrations of total brominated metabolites were $>3$-fold higher in tissue samples from Aplysina archeri than A. insularis from the same Bahamas reef (Tables $3 \& 4$ ).

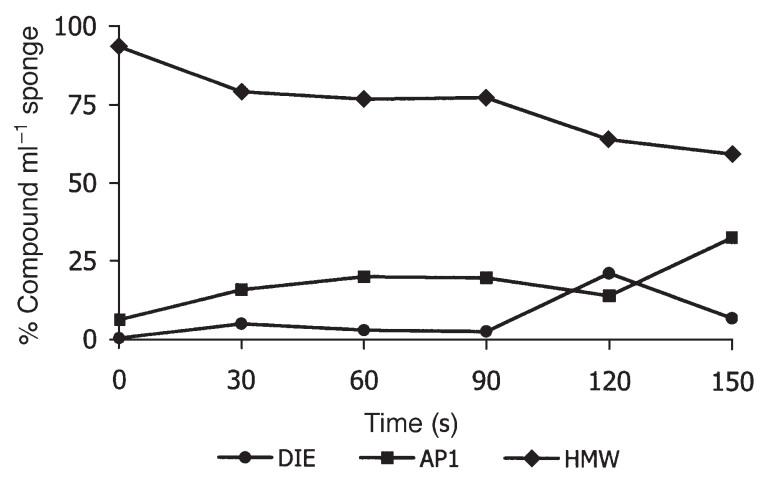

Fig. 5. Aplysina insularis. Bahamas laboratory experiment. Variation in the composition of brominated secondary metabolites in sponge tissue seconds after wounding. Percentage of total brominated metabolites as high molecular weight compounds (HMW) versus low molecular weight compounds: dibromocyclohexadienone (DIE, [1]) and aeroplysinin-1 (AP1, [2]), in crude extracts of frozen sponge tissue over a $150 \mathrm{~s}$ time course. Compounds (3) to (7) pooled as HMW (Fig. 1)

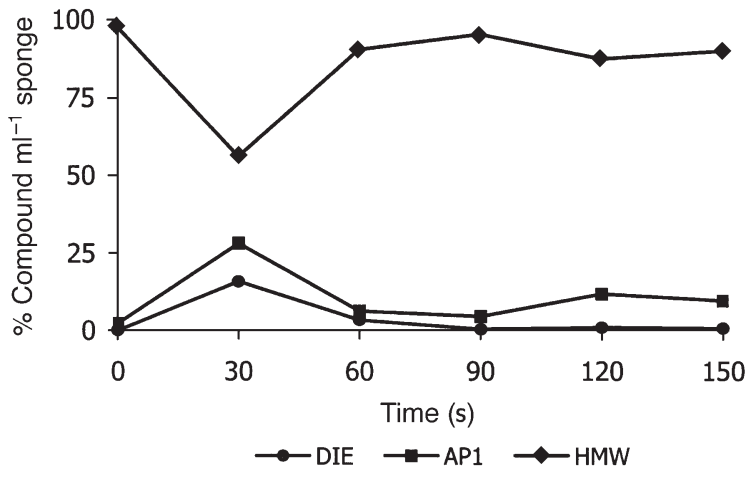

Fig. 6. Aplysina archeri. Bahamas laboratory experiment. Variation in the composition of brominated secondary metabolites in sponge tissue seconds after wounding. Percentage of total brominated metabolites as high molecular weight compounds (HMW) versus low molecular weight compounds: dibromocyclohexadienone (DIE, [1]) and aeroplysinin-1 (AP1, [2]), in crude extracts of frozen sponge tissue over a $150 \mathrm{~s}$ time course. Compounds (3) to (7) pooled as HMW (Fig. 1)

Tissue samples from $A$. insularis from Florida contained $>2$-fold higher concentrations of total brominated metabolites than those from the same species collected in the Bahamas (Tables 1 \& 2). Bahamas tissue samples of $A$. insularis also consistently did not contain aeroplysinin-1, but because these tissue samples were freeze dried prior to extraction, it is not clear whether: (1) the tissues did not contain this metabolite; (2) the solvent did not efficiently extract this metabolite from the sample; or (3) this metabolite was simply not produced as a reaction between the solvent and wet tissue. Recent studies with $A$. insularis suggest that the second of these 3 alternatives offers a partial explanation, with extraction efficiency of all brominated metabolites ranging from 0.94 to $6.20 \mathrm{mg} \mathrm{ml}^{-1}$ (>6-fold difference), depending on the extraction solvent and

Table 4. Short-time variation in the composition of brominated secondary metabolites in Bahamas samples of the sponge Aplysina archeri seconds after wounding $(\mathrm{n}=1)$. Sponges were wounded and tissue samples collected over a $150 \mathrm{~s}$ period. Quantities expressed in $\mathrm{mg}$ of compound per $\mathrm{ml}$ of sponge tissue. $\mathrm{C}=$ compound numbers, which follow Fig. 1

\begin{tabular}{|ccccccc|}
\hline \multirow{2}{*}{} & \multicolumn{6}{c|}{ Time (s) } \\
& 0 & 30 & 60 & 90 & 120 & 150 \\
\hline $\mathbf{1}$ & 0.00 & 0.92 & 0.27 & 0.02 & 0.11 & 0.07 \\
$\mathbf{2}$ & 0.64 & 1.63 & 0.50 & 0.30 & 1.44 & 1.09 \\
$\mathbf{3}$ & 15.80 & 0.68 & 1.50 & 1.35 & 2.28 & 2.21 \\
$\mathbf{4}$ & 13.84 & 1.70 & 3.66 & 3.21 & 5.41 & 5.17 \\
$\mathbf{5}$ & 4.37 & 0.40 & 1.20 & 1.08 & 1.73 & 1.69 \\
$\mathbf{6}$ & 1.71 & 0.19 & 0.42 & 0.41 & 0.69 & 0.63 \\
$\mathbf{7}$ & 1.34 & 0.29 & 0.44 & 0.31 & 0.56 & 0.54 \\
& & & & & & \\
\hline
\end{tabular}


the choice of wet-frozen tissue or freeze-dried tissue (Puyana 2001). Similar differences in extraction efficiencies have also been described for work on macroalgae (Cronin et al. 1995). It has also been suggested that the low molecular weight metabolites may arise from hydrolysis of an insoluble precursor (Andersen \& Faulkner 1972, 1974), which would not occur in the absence of water.

Does an activation of chemical defenses occur in any species of Aplysina? Based on the results of the present study, probably not. Experiments performed with $A$. aerophoba were not done with living sponge, but with freeze-dried tissue samples and cell-free extracts (Teeyapant \& Proksch 1993, Teeyapant et al. 1993a,b, Weiss et al. 1996, Ebel et al. 1997). Identical incubation experiments performed with purified substrates and cell-free extracts of $A$. archeri and $A$. cauliformis did yield 3 to $30 \%$ conversion of high molecular weight metabolites to dibromocyclohexadienone and aeroplysinin-1, but only after $20 \mathrm{~min}$ at $50^{\circ} \mathrm{C}(<2 \%$ conversion after $20 \mathrm{~min}$ at $20^{\circ} \mathrm{C}$ ), and conversion occurred only with cell-free extracts of $A$. cauliformis at this physiologically unrealistic temperature (Puyana 2001). In any case, an ecological phenomenon such as the activation of chemical defenses after tissue damage needs to be tested using living tissue, and preferably in the field, not using laboratory experiments performed with freeze-dried samples and cell-free extracts.

Acknowledgements. We wish to acknowledge the valuable assistance of M. Cueto, J. Kubanek, A. Spyere and M. Birns in performing field experiments. We also want to thank the staff of the NOAA/National Undersea Research Center at Key Largo, Florida and the crew of the RV 'Seward Johnson'. This research was supported by the National Science Foundation (CHE-9807098 to W.F. and OCE-9711255, 0095724 to J.R.P.) and by the National Undersea Research Program at the University of North Carolina, Wilmington (UNCW) (NA 96RU0260). M.P. acknowledges financial support for her graduate studies at Scripps Institution of Oceanography with fellowships from the Instituto Colombiano para el Desarrollo de la Ciencia y Tecnologia Francisco Jose de Caldas (COLCIENCIAS-Colombia) and the Fulbright Commission. We are grateful to the Government of the Bahamas for permission to perform research in their territorial waters. This is contribution no. 283 of UNCW's Center for Marine Science.

\section{LITERATURE CITED}

Andersen RJ, Faulkner DJ (1972) Antibiotics from marine organisms of the Gulf of California. In: Worthen LR (ed) Food-Drugs from the Sea, Proc 1972. Kingston, RI, p 111-115

Andersen RJ, Faulkner DJ (1974) The synthesis of ( \pm ) Aeroplysinin-I and related compounds. In: Webber $\mathrm{HH}$, Ruggieri GD (eds) Food-Drugs from the Sea, Proc 1974. Mayagüez, Puerto Rico, p 263-267

Bartlet E, Kiddle G, Williams I, Wallsgrove R (1999) Woundinduced increases in the glucosinolate content of oilseed rape and their effect on subsequent herbivory by a crucifer specialist. Entomol Exp Appl 91:163-167

Bergquist PR, Wells RJ (1983) Chemotaxonomy of the Porifera: the development and current status of the field. In: Scheuer PJ (ed) Marine natural products, chemical and biological perspectives, Vol 5. Springer-Verlag, Berlin, p 1-50

Borek V, Elberson LR, Mc Caffrey JP, Morra MJ (1998) Toxicity of isothyocyanates produced by glucosinolates in Brassicaceae species to black vine weevil eggs. J Agric Food Chem 46:5318-5323

Chanas B, Pawlik JR (1995) Defenses of Caribbean sponges against predatory reef fish. II. Spicules, tissue toughness, and nutritional quality. Mar Ecol Prog Ser 127:195-211

Ciminiello P, Constantino V, Fattorusso E, Magno S, Mangoni A, Pansini M (1994) Chemistry of Verongida sponges II. Constituents of the Caribbean sponge Aplysina fistularis forma fulva. J Nat Prod 57(6):705-712

Ciminiello P, Dell'Aversano C, Fattorusso E, Magno S, Carrano L, Pansini M (1996) Chemistry of Verongida sponges VII. Bromocompounds from the Caribbean sponge Aplysina archeri. Tetrahedron 52(29):9863-9868

Cronin G (2001) Resource allocation in seaweeds and marine invertebrates: chemical defense patterns in relation to defense theories. In: McClintock JB, Baker BJ (eds) Marine chemical ecology. CRC Press, Washington, DC, p 325-354

Cronin G, Lindquist N, Hay ME, Fenical W (1995) Effects of storage and extraction procedures on yields of lipophilic metabolites from the brown seaweeds Dictyota ciliolata and D. menstrualis. Mar Ecol Prog Ser 119:265-273

Ebel R, Brenzinger M, Kunze A, Gross HJ, Proksch P (1997) Wound activation of prototoxins in marine sponge Aplysina aerophoba. J Chem Ecol 23(5):1451-1462

Kreuter MH, Robitzki A, Chang S, Steffen R and 5 others (1992) Production of the cytostatic agent Aeroplysinin by the sponge Verongia aerophoba in in vitro culture. Comp Biochem Phys 101C(1):183-187

McClintock JB, Baker BJ (2001) Marine chemical ecology. CRC Press, New York

Paul VJ (1992) Seaweed chemical defenses on coral reefs. In: Paul VJ (ed) Ecological roles of marine natural products. Cornell University Press, Ithaca, p 24-50

Paul VJ, Van Alstyne K (1992) Activation of chemical defenses in the tropical green algae Halimeda spp. J Exp Mar Biol Ecol 160:191-203

Pawlik JR (1993) Marine invertebrate chemical defenses. Chem Rev 93:1911-1922

Pawlik JR, Chanas B, Toonen RJ, Fenical W (1995) Defenses of Caribbean sponges against predatory reef fish. I. Chemical deterrency. Mar Ecol Prog Ser 127:183-194

Pohnert G (2000) Wound-activated chemical defense in unicellular planktonic algae. Angew Chem Int Ed Engl 39(23): 4352-4354

Puyana M (2001) Chemical ecology of Caribbean sponges of the genus Aplysina. PhD dissertation, University of California, San Diego, p 214

Rhoades DF (1979) Evolution of plant chemical defenses against herbivores. In: Rosenthal GA, Janzen DH (eds) Herbivores. Academic Press, New York, p 4-54

Teeyapant R, Proksch P (1993) Biotransformation of brominated compounds in the marine sponge Verongia aerophoba. Evidence for an induced chemical defense? Naturwissenschaften 80:369-370

Teeyapant R, Kreis P, Wray V, Witte L, Proksch P (1993a) Brominated secondary compounds from the marine sponge Verongia aerophoba and the sponge feeding gastropod Tylodina perversa. Zeit Naturforsch C J Biosci 48C(7-8):640-644 
Teeyapant R, Woerdenbag HJ, Gross HJ, Proksch P (1993b) Biotransformation of the brominated compounds in the marine sponge Verongia aerophoba: evidence for an induced chemical defense? Planta Med 59(Suppl 1):A641-642

Thompson JE (1985) Exudation of biologically-active metabolites in the sponge Aplysina fistularis. I-Biological evidence. Mar Biol 88:23-26

Thompson JE, Barrow KD, Faulkner DJ (1983) Localization of two brominated metabolites, aerothionin and homoaerothionin, in spherulous cells of the marine sponge Aplysina fistularis (=Verongia thiona). Acta Zool 64:199-210

Turon X, Becerro MA, Uriz MJ (2000) Distribution of brominated compounds within the sponge Aplysina aerophoba: coupling of X-ray microanalysis with cryofixation techniques. Cell Tissue Res 301(2):311-322

Tymiak AA, Rinehart KL (1981) Biosynthesis of dibromotyrosine-derived antimicrobial compounds by the marine

Editorial responsibility: Otto Kinne (Editor),

Oldendorf/Luhe, Germany sponge Aplysina fistularis (Verongia aurea). J Am Chem Soc 103:6763-6765

Van Soest RWM (1978) Marine sponges from Curaçao and other Caribbean localities. I-Keratosa. Stud Fauna Curaçao and other Caribb Islands 179:1-94

Vetter J (2000) Plant cyanogenic glycosides. Toxicon 38: $11-36$

Walker RP, Thompson JE, Faulkner DJ (1985) Exudation of biologically-active metabolites in the sponge Aplysina fistularis. II-Chemical evidence. Mar Biol 88:27-32

Weiss B, Ebel R, Elbrächter M, Kirchner M, Proksch P (1996) Defense metabolites from the marine sponge Verongia aerophoba. Biochem Syst Ecol 24(1):1-12

Wiedenmayer F (1977) Shallow water sponges of the western Bahamas. Exper Suppl 28

Zea S (1987) Esponjas del Caribe colombiano. Catálogo Científico, Bogotá

Submitted: May 16, 2002; Accepted: August 29, 2002

Proofs received from author(s): December 9, 2002 